УдК 392.37:343.54/.55(497.11)

343.62(497.11)

316.662-055.2(497.11)

Vera GUDAC DODIĆ, Ph. D.

\title{
DOMESTIC VIOLENCE AGAINST WOMEN IN SERBIA*
}

\begin{abstract}
The history of intimidation and violence against women, within the family in Serbia, has deep-seeded roots in the past. The violent treatment of women has been woven into the foundations of society and is the result of a variety of historical, cultural, political and other factors. An analysis of the phenomenon of domestic violence against women in Serbia and the historical legacy of it are the focal points of the analysis presented in this paper.
\end{abstract}

Key words: Serbia, patriarchy, violence against women, domestic violence, subordination of women

\section{Introduction}

Violence in terms of the family and everyday life has long been glossed over and considered a taboo. The phenomenon of marriage and family violence, terminologically also marked as domestic violence, refers to all shapes and forms of violent behaviour within the family. It covers different manifestations of violence to which women, as well as, all other members of family were exposed to, thus becoming victims. Most often this referred to women and children, elder family members, the ones who were weak and unable to resist an abuser. A violent person is always the one from the closest environment, a spouse, a partner or former partner, children and parents, or other relatives, persons who live in the same household. Domestic violence has evaded influence and control of the state and its institutions for a long period of time, being deeply shrouded in privacy.

"Traditional cultures in the Balkans often support violent behaviour towards women (and children), whereby the issue is still covered with shame, which disables women to speak out and demand their basic human rights".

Domestic violence which is characteristic for all societies and social communities is widely spread. Statistics have shown that the least safe place for women is their own home. According to the statistics, the prevailing cause of death or disability in women aged between 16 and 44 is family violence, at so high a rate that exceeds cancer, traffic accidents and even war. ${ }^{2}$ In most cases, it is women who are

* This article has been written within the framework of the scholarly project Tradition and Transformation - Historical Heritage and National Identity in Serbia in 20 th Century (№ 47019), financed by the Ministry of Education, Science and Technological Development Republic of Serbia.

1 Marina Blagojević, Status of Women in Balkan Countries, Comparative Review, Belgrade, 2003, p. 135.

2 Nasilje nad ženama u porodici [Domestic Violence Against Women], Nasilje nad ženama, prepreka razvoju - međunarodni dokumenti [Violence Against Women, Obstacles to DevelopmentInternational Documents], editor Tanja Ignjatović, Belgrade, 2005, p. 79. 
the victims of domestic violence. The World Bank Report on the Status and Rights of Women published in May 2014 indicates the epidemiological levels of domestic violence against women. Appalling results reveal that millions of women worldwide were subjected to physical or sexual violence committed by their husbands or partners. "Gender based violence has reached global epidemic levels because it affects women in all parts of the world. In many parts of the world, there is no place less safe than their home because more than 700 million women are exposed to physical and sexual violence committed by their husbands, boyfriends or partners". ${ }^{3}$ Every other woman or $43 \%$ of them were exposed to this kind of violence in South Asia. Similar data pertains to women in North Africa and the Middle East where $40 \%$ were exposed to physical and sexual violence committed by their partners. The percentage of women who have been exposed to physical or sexual manifestation of domestic violence in their lives is also high in other parts of the world: $33 \%$ in South America, 30\% in East and Pacific Asia, 29\% in Central Asia, 21\% in North America, 28\% in Australia and New Zealand. ${ }^{4}$ The report of the European Union Agency for Fundamental Rights presented the violence women faced at home, work and in public reveals that every third women in the European Union suffered physical or sexual violence and one fifth of them were victim of partner related violence. Almost half of the surveyed women $43 \%$ were victims of different forms of physiological violence inflicted by their present or former partner. ${ }^{5}$

The research conducted within the territory of Serbia and former Yugoslavia has generally shown the same pattern.

Only during 2013, the total of 131 women in Serbia died as the result of family and spousal violence. ${ }^{6}$

\section{History of marriage and family violence in Serbia}

The history of spousal and family violence in Serbia against women could be seen and explained through the prism of domination of men over women and their overall position in society. The dominance of men used to be present in everyday life. The well preserved tradition and models of behaviour transmitted for generations also shaped gender relations. The warrior tradition was present in all aspects of cultural patterns and behaviour. Domestic violence was particularly characteristic in regions where family cooperatives started to gradually become smaller. The position of women and children in the family on the territory of the Yugoslav state before the Second World War was described by Vera Erlih. ${ }^{7}$

3 "Nasilje nad ženama problem u svetu" [Violence Against Women is a Problem in the World], www.Euractiv.rs/ljudskaprava/7266/nasilje (accessed: 6 November 2014).

4 Data presented in the report of the World Bank on the status and rights of women were based on a preliminary analysis of the World Health Organization in 2013, but did not include data for Europe. Ibid.

5 The report "Nasilje nad ženama, svaki dan i svuda" [Violence Against Women, Every Day and Everywhere] is based on a survey of 42,000 women, aged between 18 and 74 years. www.Euractiv. rs/ljudskaprava/6961/nasilje (access November 2014).

6 “Violence Against Women - the Most Usual Form of Women’s Rights Abuse”, http://www.euinfo. rs/sr/blog/11110/Nasilje+nad+ženama, [access September 2014].

7 Vera Erlich, Jugoslovenska porodica u transformaciji, [Transformation of Yugoslav family], Zagreb, 1971, p. 69. 
Scenes from the parents' homes, seen and learned communication between genders in family relationships, models of behaviour marked by domestic violence, encouraged and resulted in the transmission of violence from generation to generation. Subordination of women to their husbands reflected at different levels and displayed in numerous segments of life, involved violent behaviour. Such a historic legacy, powerlessness of a woman, legal as well as other dependence of women on their husbands, was the environment that not only made the violence possible, but also common.

While exploring, among other, the lives of Serbian people, Tihomir Đorđević sought to examine the position of women. He pointed to the vast differences in the position of men and women, the subordination of women that was particularly common in rural areas, such an attitude originated and went way back deep into the past. To illustrate this, he described the inhumane conditions in which rural women gave birth and the treatment of women in confinement, pointing out that women were often treated poorly; they were beaten, scolded and not allowed to rest even after the childbirth. ${ }^{8}$

Believing that man, as the master of the woman, had the right to beat her was typical of the time. The preserved records show that in the past, there were even cases of priests beating their wives. Back in 1732, in the village Livadice on the Morava River, the priest named Golub was reported to "so severely beat his wife because she drank and did not behave decently" that she ran away to Kragujevac. Nine decades later, in Kragujevac, a woman named Rista from Sirogojno, sued her husband Ilija Savić before the People's Court because he relentlessly beat her. When asked by the Court why he was doing that, he replied, "I did beat her a few times, as my wife, but not as she says..." Husbands used to beat their wives in other regions, as well. In Slavonia, wives were told "I am your God, your Court, your judgement! God created you, and I will destroy you". "A man used to be proud of having beaten his wife. Today, people are different". Vuk Karadžić wrote that a woman in Montenegro"... should be lucky to get a husband who ... does not beat her without a reason, just as he so pleases". ${ }^{10}$

Until as late as 1945, the subordination of a married woman to a man had been legally codified. According to the Serbian Civil Code, a married woman was, with respect to her general business capacity, ranked among the under-aged, the mentally disordered, the wastrels and the bums. The discrimination of women in inheritance was manifested by making the male children, that is, the male descendants the heirs, and likewise. ${ }^{11}$

The climate between the two wars in Serbia contributed to the practice of violence in the family, wrote Vera Erlih. According to the research conducted in Serbian villages and the testimonials by the villagers, beatings were frequent in families and they were approved by almost all the peasants that had been surveyed. Still, there were some exceptions. The cause of such unusual harshness towards women, according to the author, was a mixture of a number of different factors, ranging from the

8 Istorijski arhiv Beograda [Historical Archives of Belgrade], Personal Collection of Nebojša Popov, 2678, b. 15; Tihomir R. Đorđević, "Položaj žene u našem narodu" [Status of the Woman in our Society], Srpski književni glasnik, NS, XXVII, (1 August 1929), p. 528.

$9 \quad$ Ibid., p. 530.

10 Ibid., p. 531.

11 Građanski zakonik Kraljevine Srbije [Civil Code of the Kingdom of Serbia], Beograd, 1913. 
warrior tradition, the Turkish influence, and the rapid penetration of money economy. Such a set of circumstances and their specific combination brought about the use of physical force and generally harshness towards women. In this respect, there were no major differences between the patriarchal villages and those undergoing strong turbulences. ${ }^{12}$ Sayings coming from pre-war Serbia are testimony to this.

"A man should beat his wife and his horse every three days" (the county of Niš). "If you do not beat your wife for forty days, she goes mad" (the Morava County). "A man who has never slapped his wife is unworthy" (the county of Dragačevo). "A husband should beat his wife so that she knows who the head of the family is. If a wife is not beaten, she would jump over the house" (the county of Banja). "A brother and an ox should be bribed, a woman and a horse should be beaten", "Take a swing at an ox, hit a woman", (the county of Kosmaj) and many other. ${ }^{13}$

Other authors also pointed to the existence of similar sayings: "He who never beats his wife, is not a man", "A sharp-tongued woman gets beaten more often", "A wife that fears not her husband, often sheds tears" (M. Mijušković). ${ }^{14}$ They reveal the fact that the use of force by a husband against a wife in the patriarchal culture within this region used to be generally accepted. Inured to violence, they often accepted it as something inevitable.

The custom of some Serbian regions persuasively reflect the reality in which physical punishment of women was inveterate and expected. In 1940, the daily newspaper Politika wrote about customs that had been kept since "the old times" in the villages of Zaplanje region, where on the wedding day, the bride's mother would hand an iron rod to the groom, in the presence of other senior women, including the girl getting married... "So that you would beat her if she is not good. So that she would obey you as the head of the family..." after this, the wedding couple would eat fried eggs prepared by the bride's mother, as a ritual that made sure that her daughter would be subordinate to her future husband and not bring shame on her family. ${ }^{15}$

The violent behaviour against women used to have the character of a "demonstration". The villagers from the county of Vlasotince used to say that the husband would beat his wife when his parents complained that their daughterin-law had insulted them. His beating her in the presence of the children or the neighbours was considered to contribute to his authority. "A husband is the master of a wife, and he ought to beat her". ${ }^{16}$ By demonstrating power and violent behaviour against a wife in front of others, a husband would create a 'good reputation' which in itself presents the dominating and adopted values of the time and reflects the position of women, predominantly the married ones.

Violence committed within the privacy of homes and various forms and manifestations of domestic abuse, have not affected women only. Children in Ser-

12 Erlich, pp. 239, 240.

13 Erlich, p. 221.

14 Žarko Trebješanin, "Stereotipi o ženi u srpskoj kulturi“ [Stereotypes About the Woman in Serbian culture], (http://beogradskaka5anija.cyberfreeforum.com/t4105-stereotip-o-zeni-u-srpskojkulturi) [accessed 1 June 2012].

15 D. I. Jovičić, “Po Zaplanju” [Across Zaplanje], Politika, 18 July 1940, p. 11.

16 Erlich, p. 240. 
bia ere often beaten by their parents. Corporal punishment of children was part of their upbringing, family life and growing up. ${ }^{17}$

\section{Domestic violence against women in the socialist period}

This legacy, shaped and born out of the controversies of the past as the outcome of historical and cultural influences was inherited by the socialist government. In the socialist period, the Yugoslav state criminal law did not treat or regulate domestic violence as a separate criminal offense, but instead, some other provisions of the criminal or other laws were applied. A special Article in the Law on Amendments to the Criminal Code regulating sanctions against domestic violence, that recognized it as a separate criminal offense for the first time, was passed as late as 2002. ${ }^{18}$ The introduction of domestic violence as a separate, independent offence in criminal legislation was preceded by, among other, numerous activities of different organizations. Particularly sensitive to its victims, and active against domestic violence have been women's organizations and groups who lobbied for the change of law.

The violence woven into everyday lives of many women embodied a dark side and a distressing picture of life. For quite a long period, the modernization of the socialist state was resisted by the accustomed behaviour relying on the belief that "a wife is subordinate to a husband, she must obey him. Hence the beating of wives..." ${ }^{19}$ Unequal distribution of power and patriarchal cultural patterns from which the violent treatment of women originated, prevailingly dominated in rural environment. The recollections of peasant women reveal instances of domestic violence committed by a member of the extended family. Mira Dervišić married when she was not yet 16 to a man form the village of Debeli Lug near Majdanpek in 1970s. She replied to a question whether her mother in law ever hit: "My mother in law? Yes, she hit me once. She hit me with a piece of wood, hit me on the head. She did, she did. My father in law hit me twice and I cried, he grabbed my hand and said: Don't cry, it is no big deal..."

Despite the leftist political orientation of the government promoting gender equality, at least at a declarative level, with the state adopting laws to eliminate the inherited legally founded discrimination of women, domestic violence continued to be invisible for the socialist state. Domestic violence evaded social control, while aggressive behaviour by some family members remained within the boundaries of privacy, behind the locked doors and hidden from the public. It would be revealed only in extreme cases or before courts when spousal abuse would lead to divorce. The fact that there were not many records of domestic violence in the period of socialism likewise shows that violence was treated as a private family matter.

Spousal abuse, the most frequent form of violence in Serbian families, often resulted in marriage breakdown and consequentially, divorce. The abusive

17 Vera Gudac Dodić, „Život u senci zla, nasilje u braku i porodici“ [Life in the Shadow of Evil, Domestic Violence], Tokovi istorije, [Currents of History] (3), Belgrade, 2012, pp. 226-241.

18 "Krivični zakon Republike Srbije", [Criminal Code of the Republic of Serbia], Nasilje u porodici, [Domestic violence], clause 118a, 76, Official Gazette of the Republic of Serbia, Belgrade, 2002.

19 Arhiv Jugoslavije, (Archive of Yugoslavia) (AY), 837, KPR, II-2/16, 1953.

20 Ja, žena sa sela [Me, a Countrywoman] Sandra Mandić, coverage, TV B2 production "Redakcija" [Redaction] February 8, 2010. 
behaviour of spouses used to be and remained one of the major reasons for divorce. Aggressiveness and physical abuse in family life is linked with alcohol abuse, in most of the cases by a husband. Alcoholism frequently precedes and accompanies violence. Under the influence of alcohol, almost always provoking a range of problems, husbands would quite often harass their wives both physically and in other ways. "They had a bad life together from the very beginning, because the husband used to drink, and he would have an intercourse with his wife in such a state and would also beat her" or "he would return home late, which caused serious fights, and even physical attacks, due to which the marriage became impossible to keep", ${ }^{21}$ are only some of the segments of the hidden family dramas, preserved in the documents dating from the beginning of the second part of the $20^{\text {th }}$ century. When women initiated a divorce, which was less often in the early 1950s in Serbia, with the exception of Belgrade, considering that it was predominantly the men who instigated the divorce action, they were often motivated by the physical abuse they had been exposed to "in view of the fact that the petitioner beat the respondent (wife)", "physical attacks were occasional" etc. ${ }^{22}$

\section{Last decade of the $20^{\text {th }}$ century: war conditions and social crisis as generators of violence}

In the 1990s of the twentieth century, during the civil war in Yugoslavia, amidst the social, economic and political crisis that fundamentally shook Serbia, the family was equally affected. The crisis that was manifested in all spheres of social life, bringing chaos and despair, accompanied by the dusk of almost all values of the ethical code upheld until then, degraded the position of the majority of the population, but it was the women who carried its full burden. The decline in production and employment, multitude of people laid off with underground economy concurrently flourishing, poverty brought to its extreme limits, are only a part of the picture of economic and social environment in Serbia in the last decade of the twentieth century.

Migration, conflicts and bombing of the FRY in 1999 also marked this period. The social transition in the late $20^{\text {th }}$ and early $21^{\text {st }}$ century, led to many changes. The research showed that these processes, among other, had the destabilizing effect on families and family relationships. The dysfunctional family relationships often ended in violence, whose victims, in most of the cases, were women and children. The studies on domestic violence in former Yugoslavia showed that the war, economic crisis and social transition were powerful generators of domestic violence. ${ }^{23}$ Conditions that favour the increase of violence in the society reflected on the family as well, and therefore contribute to an increase in domestic violence.

Any form of family violence, physical abuse, psychological abuse, threats, including sexual abuse, are more frequent in poor families in Serbia and in

21 AY, AFŽ, 141, 33, Razvod braka u Srbiji, [Divorce in Serbia] 1952.

22 Ibid.

23 Sanja Ćopić, "Porodično nasilje u zemljama bivše Jugoslavije: pregled najvažnijih rezultata istraživanja" [Domestic Violence in Countries of the Former Yugoslavia: Review of the Most Important Results of the Surveys], Temida, 6 (2), Belgrade, 2003, pp. 17-25. 
those whose financial status had declined, that is, those which became poorer. The violence exerted on women is more frequent in families living in extremely underprivileged conditions. Data revealed that, with the exception of sexual abuse, that women living in various forms of extended families or households are more exposed to violence. Some authors find that with regard to the exposure of women to domestic violence, particularly risky form of household is the vertically extended family. ${ }^{24}$ Unemployment among men and family situations where a partner constantly earns less than a wife or whose wages have been considerably fluctuating, also provoke domestic violence. This is more evident in families whose idea of the traditional role of a man as the provider has been undermined. The war extensively triggered domestic violence: the connection between the participation of men in war and violence in the family was established. Reasons that prevented a woman from leaving a violent partner were chiefly existential: they could not support themselves, they were unable to take care of the children, had no apartment and/or place to go to. This was specified as the main reason among women who had never attempted to leave the abusers, or who had left them, but returned later on. At the same time it was noticed that among the women who left the abusers, the largest proportion considered themselves to be the main providers, which indicates the importance of economic and financial independence of women as the key factor in finding the way out of domestic violence. Fear for their children is also among the important reasons declared by women that had stopped them from leaving a violent partner as did hope that the partner would change etc. ${ }^{25}$

Domestic violence in Serbia is considerably widespread, while women who suffer it belong to different social strata, different education and profession. The moment when they are most vulnerable is when they decide to leave the abuser. Physical abuse of women is most often repeated and becomes more brutal over time. After a period of remorse for committing "evil", again there is a phase of violence. Women are afraid of the abuser's retaliation, and the majority of murders in family occur when a woman tries to leave. ${ }^{26}$

\section{Contemporary context of domestic violence in Serbia}

Research on violence taking place in the privacy of the home in Serbia is of recent date, mostly conducted after the year 2000. It invariably shows that domestic violence in the contemporary conditions constitutes a part of the daily life of many women. One of the first research projects dealing with this issue was carried out by the Victimology Society of Serbia at the beginning of the twenty first century. The research on domestic violence in Serbia, its characteristics and expansion carried out in 2001, showed that a high percentage of women had been exposed to some of its forms or manifestations. The results of the research that

24 Vesna Miletić-Stepanović, "Nasilje nad ženama kao rizik za socijalnu transformaciju”, [Violence Against Women as the Risk for Social transformation], Temida, 8 (1), Belgrade, 2005, p. 25.

Ćopić, pp. 23, 24.

26 Nevenka Petrušić, Slobodanka Konstantinović Vilić, Vodič kroz sistem porodičnopravne zaštite od nasilja u porodici, [Guide to the System of Legal Protection from Family Violence], Belgrade, 2006, p. 10. 
included 230 women from the territory of Belgrade, 120 from the territories of Novi Sad and Niš, 60 from each of the towns of Užice, Zaječar and Vrnjačka Banja and 50 from the territory of Subotica, have been presented in the book titled The Domestic Violence in Serbia. ${ }^{27}$ According to the obtained results, almost one half of surveyed female population suffered the psychological abuse in their families (46.1\%), slightly below one third of surveyed women $(30.6 \%)$ were exposed to physical abuse, while each fourth woman was threatened with violence $(26.3 \%)$. The psychological abuse suffered by the women was manifested in different ways. The survey respondents specified as the most common forms of abuse they suffered, scolding, name calling, swearing and other forms of contempt and humiliation, followed by the restriction of movement or contact with other people, or more specifically isolation. They indicated that they had been psychologically and emotionally abused by arguing, shouting, rebukes, drunkenness, jealousy, etc. Economic violence for many women meant limiting or completely restricting their use of money, preventing them to work, insisting that they leave their jobs, etc. Threats and intimidations are manifested through various forms of blackmail, such as those that he would take her child from her, kick her out of home and other. Some respondents specified the use of different privileges, instructing them to behave in specific way and similar, as the forms of psychological violence. ${ }^{28}$

The highest percentage of respondents who experienced physical violence in their own homes, manifested as slapping (12\% of women have experienced this form of violence) and battery (9\%). Other examples of physical abuse of women were reported as well. It is indicative that the highest percentage of women who have been physically abused is among those aged above 65 . Women have been most frequently physically abused by the spouse, the percentage of husbands as the offenders being particularly high, reaching $74.8 \%$. In a much smaller percentage, the survey has shown that also other family members and even former partners appear to be committing violence. $7.4 \%$ of women were exposed to violence involving weapons or tools that may cause serious injuries. Cases of forced sexual acts were recorded in $8.7 \%$ of women. ${ }^{29}$

The data presented in this survey is testimony that violence against women in Serbia is widespread, with the percentage of women being victims of physical abuse in their families, higher than those recorded in Western countries, or those form the neighbouring countries. Moreover, the results show that the most common, albeit not the only abuser in the family appear to be the man, in particular the husband, or the partner. Being under the influence of alcohol is conducive to violence. Often, but not most frequently, violence is committed in a state of drunkenness. Exposure of children to either direct or indirect violence has also been reported. The obtained results emphasize the importance and impact of two major factors on occurrence of domestic violence, in particular: patriarchy and financial constraints. ${ }^{30}$

27 Vesna Nikolić-Ristanović, Porodično nasilje u Srbiji [Domestic Violence in Serbia], Viktimološko društvo Srbije [Victimology Society of Serbia], Belgrade, 2002.

28 Ivana Vidaković, „Rasprostranjenost nasilja u porodici“ [The Prevalence of Domestic Violence], Porodično nasilje u Srbiji, [Domestic Violence in Serbia], pp. 13-19.

29 Vidaković, ibid., pp. 39-61.

30 Nikolić-Ristanović, Porodično nasilje u Srbiji [Domestic Violence in Serbia], pp. 107, 108. 
One decade later, research was conducted on characteristics of family violence on the territory of Serbia proper. ${ }^{31}$ It indicates that domestic violence is still widespread, to the extent that more than one half of female respondents (54\%) have had certain experience related to family violence. The most common form in central Serbia is psychological violence, then physical, economic, and finally sexual abuse. One third of women-respondents have simultaneously suffered different forms of violence in their own home. Women who were exposed to violence in this area differed in education and schooling, age. Furthermore, they lived in different settlements and environments, belonged to different social strata and had different family status. The research confirms that the most common abuser in the family is a husband or a partner. It shows that "structural, cultural and individual factors of violence are less important than the family ones and they are mediated by them." ${ }^{32}$ The same as in the previous research related to the phenomenon of domestic violence in Serbia, it has been noted that poverty contributes to violence within family, in other words it increases the risk of exerting violence against women. Cultural factors did not have a significant impact on the appearance of violence, and more liberal position of women in terms of gender roles was neither an obstacle to domestic violence nor did it raise the risk of its appearance. The position of a partner did have greater influence on violence. Women who were in relationship with persons with more liberal stances were rarely exposed to domestic violence, whereas the ones whose partners advocated patriarchal views were at greater risk to be subjected to various forms of abuses and violence. Women's economic independence and employment is a precondition for the risk of family violence to be lower, but it is not sufficient for its prevention. Speaking of family factors, the problems such as alcoholism, drug addiction, "take the lead as predictors of family violence","33 as the research concludes. Life in larger, multifamily households increases the risk of women being exposed to domestic violence and abuse by several members. "It should be emphasized that one third of abused women who live in larger households has experienced violence from the three key segments of their primary social networks: from the family of origin, from the husband and his family and from their own children. Life in such a circle of violence, in conditions of distant, low-quality and non-efficient support services, does not provide women with a single way-out from the life marked by violence". ${ }^{34}$ Women rarely turn to an institution for help..$^{35}$ Abusers were, at least for a short period of time, abandoned by only one third of women who were victims of violence, whereas fewer women tried to divorce or to make them apply for some kind of therapy. The majority of women adapted themselves to life in which violence was a common episode and its inevitable part.

31 Marija Babović, Katarina Ginjić, Olivera Vuković, Mapiranje porodičnog nasilja prema ženama u Centralnoj Srbiji [Mapping of Family Violence Against Women in Central Serbia], Belgrade, 2010.

32 Ibid., pp. 91-92.

33 Babović, Ginjić, Vuković, ibid., p. 92.

34 Ibid.

35 This research discovered omissions in the work of institutions that are supposed to provide assistance to victims of violence. Doctors would sometimes provide medical help to victims, neither asking them about the origin of injuries nor taking any further action. Also, there were examples that a Social Care Centre did not report case of domestic violence, etc. Babović, Ginjić, Vuković, p. 93. 
Research on violence in personal relationships conducted in an urban environment, in Belgrade, the capital of Serbia, also revealed that women were often exposed to violence. ${ }^{36}$ According to the research, $23.7 \%$ of women from the surveyed sample who had been in intimate relationships during some period, had been exposed to violence (physical or sexual) at some time in their lives. Physical violence against them took on various forms of slapping, targeting with various objects, pushing, kicking, beating, punching, choking, causing burns, and other. The fact that one in five of women from the group that was exposed to violence suffered serious injuries completes the picture of domestic violence against women. Among respondents covered by the study, who reported that they were pregnant, $3.4 \%$ were victims of physical abuse by their partners during pregnancy. ${ }^{37}$ This and other studies, confirm that the social status and educational level of women is not an obstacle to violence and that it is present in all social groups.

A high percent of alcoholics among abusers proves that alcohol contributes to an increase in violent behaviour of men. The research conducted using the data gathered from the SOS emergency phone for women and children victims of violence in Belgrade indicates that alcoholism initiated violence in $33.5 \%$ of cases. ${ }^{38}$ Speaking of family violence, alcoholism was often accompanied by some other causes (jealousy, return from the war arena, etc.). Female victims of violence who sought help by means of SOS emergency phone often stated, in $49.2 \%$ of cases, that violence was not provoked, in other words that it appeared without any reason. Jealousy was the cause of violence in $10.2 \%$ of cases, problems related to apartment in $9.3 \%$, money in $8.5 \%$, and children in $5 \%$ of cases. Other causes were indicated in $11.1 \%$ of cases. ${ }^{39}$ The fact that alcohol contributes to violence does not mean that it provokes it, but that it serves as a mechanism for the loosening of inhibitions that prevent men from behaving violently towards their female partners. ${ }^{40}$ Therefore, it is better to say that alcohol and violence overlap than that alcohol causes violence.

The prevalence of domestic violence has also been confirmed by the research conducted in Vojvodina, implemented by the Victimology Society of Serbia. It included 516 women from seven cities and forty villages in Vojvodina. More than half of the women who participated in the survey confirmed that they had experienced some form of violence. One half of respondents experienced psychological abuse (49.8\%). About one third of respondents $(27.3 \%)$ had been exposed to physical abuse, and more than one third (33.9\%) were its victims. Sexual abuse in family was experienced by $9.1 \%$ of women from the survey sample. In most of the cases, the abuser was a spouse or ex-husband, or the current or former partner. ${ }^{41}$

36 Nasilje u partnerskim odnosima i zdravlje [Intimate Partners Violence and Health], editor Stanislava Otašević, Belgrade, 2005.

37 Ibid., pp. 25, 28.

38 Some other research present much greater percent of violence exercised in the state of intoxication.

39 Mršević Zorica, Ka demokratskom društvu - rodna ravnopravnost [Towards Democratic Society Gender Equality], Belgrade, 2011, p. 58.

40 Mršević, p. 50.

41 "Nasilje nad ženama u svetu i kod nas" [Violence Against Women in the World and in Our Country], 


\section{Certain characteristics of family violence against women}

Adaptation to violence within a family is of great importance for the understanding of this phenomenon. Both abusers and victims of violence often came from families in which domestic violence had been exercised on a regular basis, and they had been either victims of violence or observers of violent scenes. Some research indicate that male children who grew up in families characterised by violence are often prone to such reactions, or applications of the learned model of behaviour, more than other children who did not grow up in environment in which domestic violence occurred regularly. On the other hand, women who used to be victims of violence at their early age, or witnesses and observers, have more chance to be "abused" in partner relationships. According to research pointed out by Z. Mršević, $27 \%$ of women who experienced sexual abuse as minors were later raped, whereas other women had the same experience in $8 \%$ of cases. Speaking of sexually abused girls and minors, many of them, even $40 \%$, were later beaten or raped in marriage. When it comes to women who did not have such experiences in their childhood or youth, the percent of the ones who were beaten or raped as grown-up women in marriage was lower, $14 \%{ }^{42}$

While analysing the phenomenon of family violence, certain researchers paid special attention to so-called psychopathic violence in the family, and to characteristics and consequences of such violence. ${ }^{43}$ Anglo-Saxon research has established that a considerable number of perpetrators of violence against women are persons with so-called "antisocial personality disorder". ${ }^{44}$ Family violence that they exert partially differs from and indicates particular characteristics compared to domestic violence that is exercised by persons who are not characterized by this kind of psychopathic personality. The risk that domestic violence will appear, as well as that it will manifest again, is greater among abusers with psychopathic personality then among the others. Contrary to abusers who exercise violence at the moment of great emotional thrill, based on particular reason, either real or experienced in such a way by the abuser, a psychopath does not need any motive to carry out a violent act. Violence is planned and premeditated, cold-blooded, performed without emotions. Although it looks as if perpetrators are extremely angry and furious at the moment of exercising violence, they actually work themselves up into a fury intentionally, almost acting, and they are able get themselves out of such state in the same way. Psychopaths are able to stop, to make a pause during the very act of violence, e.g.

Republika Srbija, Autonomna Pokrajina Vojvodina, Pokrajinski sekretarijat za rad, zapošljavanje i ravnopravnost polova. (http://www.hocudaznas.org/publikacije/Cinjenice-i-brojke-o-nasiljunad-zenama) [accessed 1 December 2013].

42 Mršević, p. 58.

43 Danka Radulović, "Osobenosti i posledice psihopatskog nasilja u porodici” [Characteristics and consequences of psychopathic violence in the family], Temida, 2005, pp. 11-19.

44 Psychopathy is defined as "relatively permanent state of structural psychological personal disorder characterized by: particular set of personal characteristics dominated by aggressiveness; anti-social, egoistically-hedonistic value orientation with the conspicuous lack of moral and evil intentions; and behavioural manifestations of behavioural disorder, among which perpetration of criminal acts particularly stands out". Since psychopaths understand social regulations and behavioural norms, "they must be considered mentally capable and criminally responsible". Radulović, p. 13. 
to answer the phone and to talk quietly and calmly, even kindly, and then attack its victim even more violently. ${ }^{45}$ While the majority of persons who do not have characteristics of psychopaths exert violence in the state of great emotional thrill, and completely possessed by rage, the situation with psychopaths is opposite. Their planned, cold-blooded violence does not provoke remorse. Psychopaths are the most violent persons who abuse their wives and children all the time, and their families are exposed to the greatest risk of repeated violence. Abusers with psychopathic personality are almost resistant to treatments, even the ones particularly created for abusers. Good at camouflage and manipulation, they force their victims to utter and unquestioning submission. ${ }^{46}$

\section{Judicial practice}

Practices of the Prosecutor's Offices and Courts in processing criminal offences of family violence were subject of a research carried out in Belgrade and Niš. ${ }^{47}$ The analysed sample in Belgrade was composed of 420 items (280 prosecutors' cases and 140 court cases), and in Niš 59 court cases and 50 prosecutors' cases. According to the said sample, the greatest majority of perpetrators were male (92\%), mainly aged between 33 and 40. Abusers and victims were mainly married, or divorced. The majority of abusers were employed, and had secondary school education. In the examined sample, the greatest number of violence executers were born and lived in towns. Among perpetrators of the criminal offence of family violence there was a slightly greater number of persons who had not been convicted before. The majority of them were of sound mind at the moment of carrying out criminal offence. A smaller number of them, $40 \%$, were not intoxicated, whereas the others were. Usually, they did not admit to the deed they had performed. The greatest number of victims of violence, even more than 80\%, were women. Persons aged between 41 and 56 prevailed among the victims. Children appeared as perpetrators of violent acts and parents as victims in around $15 \%$ of cases. In the greatest majority of cases violence had been practiced for a longer period of time. In more than a half of the cases victims suffered from physical violence, in $40 \%$ physical and psychical, and in the rest only from psychical violence. Criminal charges were mostly brought by the police. The study concludes that understanding continuity of domestic violence as an important feature of family violence has not been completely acknowledged in practice, though the situation is better than before. Several charges were rejected "based on an explanation that the manifested violence was accidental as the suspect has not been convicted before ${ }^{\prime 4}{ }^{48}$ Around 30\% of charges were rejected due to lack of evidence, as it was provided. When a prosecutor received criminal charges, he would usually not talk to a victim. The police was the one who did

45 Radulović, pp. 13, 14.

46 Radulović, pp. 17-19.

47 Slobodanka Konstantinović-Vilić, Nevena Petrušić, Krivično delo nasilja u porodici, aktuelna pravosudna praksa u Beogradu $i$ Nišu [Criminal Offence of Family Violence, Current Court Practice in Belgrade and Niš], Belgrade, 2007. 
that. According to the research, in judicial practice the idea of "family member" was interpreted in different ways, sometimes very restrictively, which conditioned the narrowing of range of family violence protection. The study emphasizes that "there are neither mechanisms that would make the courts and the prosecutor's offices accept the same stand on certain elements of the criminal offence of family violence, nor has uniformity been reached within these judicial institutions ". ${ }^{49}$ Also, it has been established that imposed sentences "indicate a tendency towards mild punishment: offenders are mainly charged a fine or put on probation, whereas effective prison sentences usually last for legal minimum time". ${ }^{0}$

Other attempts to consider judicial practice in the Republic of Serbia related to family violence and imposed sentences ${ }^{51}$ were based on an analysis of data obtained through information requests. Requests were sent to 20 courts in various regions. ${ }^{52}$ The research shows, among other, that from the moment the criminal offence of family violence was introduced in 2002, the number of court proceeding was constantly rising. This could be explained by an increased number of family violence cases, as well as a raise in their processing. According to the tested sample, sentences imposed for cases of family violence in Serbia were as follows: terms of probation in around $67 \%$ of cases, fines in $15 \%$, prison sentence in $11 \%$ and protective measures in about $7 \%$ of cases. ${ }^{53}$

The study that focused on abuser's gender and its influence on processing of family violence cases, and on other factors that affect the implementation of legal provisions, examined cases in which either men or women were accused, cases in which they were mutually accused, or "in which men and women are both victims and perpetrators." ${ }^{54}$ Men are more often arrested for family violence ${ }^{55}$ and they are more often subject to a fine or prison sentence. A significant link has not been established yet between gender and prison sentence, but it has been

49 Ibid., p. 109.

50 Ibid., p. 110.

51 A research for the period 2009-2010 was conducted by the organisation "Pravni skener" (Legal Scener) in cooperation with the association "Dijalog" (Dialogue).

52 Judicial practice has been analysed based on verdicts in accordance with the Criminal Code (Article 194), but not on legal proceedings, as it was not possible to acquire copies of all effective verdicts that have been reached based on the Family Law. "Family violence, the penal policy of courts" http://www.pravniskener. rg/ljpp01.htm\#sthash.cvEUgQnY.dpuf. [accessed 5 September 2014].

53 The measure of providing treatment to alcoholics used to be imposed as a protective measure. This research emphasizes that protective measures, particularly the one related to medical treatment of alcoholics, were imposed in only 6 to $7 \%$ of cases, despite a great number of cases of violence executed in the state of intoxication. There were differences between courts when imposing fines. "Family violence, the penal policy of courts".

54 Vesna Nikolić-Ristanović, Praćenje primene zakonskih rešenja o nasilju u porodici u Srbiji: nalazi pilot istraživanja, Un Women, 2013 [Supervision of the Implementation of Legal Solutions to Family Violence in Serbia: results of a pilot study, Un Women, 2013]. http://Pracenje primene zakonskih resenja o nasilju u porodici u Srbiji. [accessed 5 September 2014]. The research was conducted based on the sample of 219 men and women who were convicted in 2007, 2008 and 2009 in Niš (18.3\%), Kruševac (15.5\%), Leskovac (6.4\%), Valjevo (12.8\%), Veliko Gradište (10.5\%), Obrenovac (14.2\%), Lazarevac (8.7\%) and Aleksinac (13.6\%).

55 From 2007 to 2009, women constituted a smaller percent of the total number of persons charged for the criminal offence of family violence, but a raise in the number of accused women in 2008 was greater than a raise in the number of accused men. Ibid., pp. 4, 5. 
noticed that other factors have a decisive impact on imposition of prison sentence. According to this research, courts will more often impose a prison sentence if family violence is treated as "part of the wider context of long-term violence", and the possibility that a perpetrator of the violent act be imposed a term of probation or a prison sentence increases with "a raise in the seriousness of an offense". The decision to arrest and impose a prison sentence is greatly influenced by the circumstances in which spouses, as well as other members of family are abused (children, parents...). If a violent act is committed in the state of intoxication, sometimes protective measures are undertaken based on abuser's treatment, but this does not refer to all cases. Decisions regarding probations and charges, according to this research, are mostly influenced by the existence of previous charges for family violence, in other words the knowledge that a perpetrator has a history of repeated violence offences. Previous charges are important for other criminal acts, as well. "This research speaks in favour of the existence of significant gender implications when it comes to the implementation of legal solutions to family violence in Serbia, rather than of the direct discrimination of women. The mentioned implications generally refer to an inadequate treatment of cases in which there is continuous violence (usually violence of men toward women), as well as of cases of mutual violence in which a victim (usually the male one) is a primary offender, but a woman, who is a primary victim, is condemned. ${ }^{\text {"57 }}$

\section{Culprits or victims}

The background and life stories of women who had been victims of domestic violence, sentenced for criminal offenses, described in the study on domestic violence and crimes committed by women constitute the harrowing testimony of the causes, nature and consequences of violence. The study was based on the testimonies of female prisoners of the Correctional Institution Požarevac. The study included a sample of 20 women who, at the time, in late 1997 and early 1998, were undergoing sentences of imprisonment. Most of the respondents, more specifically sixteen of them, were convicted of murder. ${ }^{58}$ The lives of these women had been marked by violence, both the one they had been exposed to in their daily lives and which they had endured for years, and by the criminal act that they eventually committed. The time periods during which they had been exposed to domestic violence differ, from six months to forty years. In most cases, the violence had persisted for more than five, for many of them over ten years, and it took place in the period of the socialist state. The attempt to form a clear picture using different individual experiences of women who lived with the abusers, only confirmed the existing findings. Most male abusers have encountered violence against their mothers by the fathers in their childhood which apparently points to the intergenerational transmission of violence. Male socialization inherent in traditional patriarchal forms of upbringing, and violence as a pattern of behaviour seen and learned in the elementary family,

56 Ibid., p. 44.

57 Ibid.

58 Vesna Nikolić-Ristanović, Od žrtve do zatvorenice, nasilje u porodici i kriminalitet žena, [From Victim to Prisoner, Domestic Violence and Crimes Committed by Women] Belgrade, 2000, pp. 32, 35. 
has been the significant precursor of aggressive behaviour. At the same time, the marginalization of women in many perspectives has also been one of the factors conducive to violence. Women who encountered physical abuse and violence in marriage for the first time, would be stunned and surprised, less prepared to confront the abuser, than those accustomed to such patterns of behaviour, having encountered it in childhood. Where they attempted to resist the perpetrator and leave, the perpetrators would become more aggressive, they would be beaten more fiercely and the violence they suffered would become more severe. Without any adequate support by either the society or their immediate environment, they gradually became overwhelmed by the feeling of helplessness. At some point the whole situation is upturned, and many of them, often when violence culminates, commit crimes, even the most serious ones the murder. The offenses committed by the respondents for which they were convicted, and their criminal behaviour had been directly or indirectly related to the violence that they had survived. Although 'violence is not in itself a justifying reason for committing a criminal act' usually the criminal behaviour of these women would not have occurred if they had not been exposed to violence. ${ }^{59}$

\section{Conclusion}

Almost all societies are familiar with family violence. Conditioned by historical and socio-economic factors, domestic violence principally originates from patriarchal, unequal power relations between men and women. It is deeply woven into the fabric of society, based on the model of male domination over women, devised to ensure keeping control over them. In traditional cultures, domestic violence stemmed from the very structure of the society. Historical legacy, women's weakness and their legal and other dependence on a husband, favoured relations in which the use of violence was common. Despite changes in the status of women, domestic violence was invisible in the period of socialism, as it was treated as the matter of family privacy. At the end of the $20^{\text {th }}$ century, deep social and economic crisis, war, and social transition, contributed to a raise in domestic violence. Family violence was first established as a separate criminal offence in Serbia in 2002. The research on domestic violence, conducted in different parts of Serbia, has shown that it is characteristic of both the rural and urban areas and has discovered a large number of women who experienced it, either in the form of physical or some other violence. Domestic violence is widespread in Serbian society, and women who endure it come from various social strata, they have different levels of education and professions. It usually occurs in poor families, as well as in different forms of extended families. Some research on the judicial practice of penalty imposition for the criminal offence of family violence implies that evidence pointing to repeated violence, as well as a history of previous criminal charges for other violent criminal acts, have most influence on the prosecutor's decision whether to punish a perpetrator or not.

59 Ibid., pp. 104-114. 


\section{Резиме}

\section{Насиље над женама у породици у Србији}

Кључне речи: Србија, патријархарт, насиље над женама, насиље у породици, подређеност жена

Милиони жена у свету које су биле изложене породичном насиљу сведоче о његовој распрострањености. Истраживања спроведена на подручју Србије уклапају се у такву општу слику. Историјат насиља над женама у кругу породичне приватности снажно је повезан са праксом подређености жене мушкарцу. До завршетка Другог светског рата инфериорност и подређеност удате жене мужу имала је у Србији своје законско упориште и одсликавала се на многе сегменте живота. Родни односи засновани на патријархалном устројству друштва и моделима моћи, те традиционалним образцима и нормама понашања, омогућавали су појаве насилничког понашања према женама. Упркос левичарској идеологији владајућег поретка, који је макар декларативно промовисао родну равноправност, а држава законима уклањала затечену правну утемељеност дискриминације над женама, за социјалистичку државу насиље у породици и даље је било скривено и утопљено у сферу приватности. Деведесетих година двадесетог века, у условима грађанског рата у Југославији, друштвена, економска и политичка криза која је из темеља потресала Србију одражавала се и на породицу. Истраживања о насиљу над женама у приватности дома и породице у Србији новијег су датума. Она без изузетка показују да је породично насиље у савременим условима део свакодневице и сведоче о високом проценту жена које су биле изложене неком од његових облика и манифестација. Најчешће насиље над женама врши супруг, односно партнер. Домаће насиље је присутно у свим социјалним групама. Виши ниво образовања жене и мушкарца није препрека испољавању насиља у породици. Алкохол, мада није његов узрок, повећава насилничко понашање мушкараца. Поједини истраживачи су у анализи феномена породичног насиља посебну пажњу усмерили на насиље које су починили људи са тзв. „антисоцијалним поремећајем личности“. Њихове жене и чланови породичног домаћинства изложени су жестоком насиљу вештих манипулатоpa, а шансе за понављање насиља у овим случајевима су велике. Континуитет породичног насиља, односно чињеница да починилац понавља ово дело, према различитим истраживањима судске праксе у Србији има, поред тежине извршеног дела, највећи утицај на судске одлуке о притвору насилника и изрицању затворске казне. 